\title{
Nine-year follow up after hematopoietic stem cell transplantation in five multiple sclerosis patients
}

\author{
Nove anos de seguimento após transplante autólogo de células tronco hematopoiéticas \\ em cinco pacientes com esclerose múltipla
}

Elizabeth R. COMINI-FROTA', Bruna C. C. MARQUES', Caio TORRES1, Karoline M. S. COHEN'1 Eduardo

Carvalho MIRANDA²

\begin{abstract}
Multiple sclerosis (MS) is an immune-mediated disease of the central nervous system. Its treatment has focused on inflammation control as early as possible to avoid disability. Autologous hematopoietic stem cell transplantation (AHSCT) has been used for treating MS since 1996, with recent decisive results regarding benefits in long-term efficacy. Five patients followed up at an MS center in Belo Horizonte, Brazil, who had relapsing-remitting MS with high disease activity, underwent AHSCT between 2009 and 2011. They were evaluated clinically, with magnetic resonance imaging, and by the EDSS every six months after transplantation, up to July 2018. The patients were four women and one man, with ages ranging from 25-50 years, and time since disease onset ranging from 4-17 years at the time of the procedure. Four patients improved, one patient was stabilized, and all patients were free of disease activity after 5-9 years. Through improving patient selection and decreasing the time from disease onset, AHSCT could stop epitope spreading and disease progression. Despite multiple other therapeutic choices being approved for relapsing-remitting MS, AHSCT continues to be a treatment to consider for aggressive MS disease.
\end{abstract}

Keywords: Stem cell; autografts; multiple sclerosis; therapeutics.

\section{RESUMO}

A esclerose múltipla é uma doença imunomediada do sistema nervoso central. Seu tratamento tem sido focado no controle da inflamação o mais cedo possível para evitar incapacidade. O transplante autólogo de células tronco hematopoiéticas (TACTH) vem sendo usado para tratar esclerose múltipla desde 1996, e recentes resultados foram decisivos a respeito do benefício na eficácia a longo prazo. Cinco pacientes seguidos num centro de esclerose múltipla de Belo Horizonte, Brasil, que apresentavam forma clínica remitente recorrente com alta atividade de doença foram submetidos a esse tratamento de 2009 a 2011. Após o transplante foram avaliados clinicamente e com ressonância magnética, e escala de EDSS, a cada seis meses até julho de 2018. Os pacientes eram quatro mulheres e um homem, com idade entre 25 e 50 anos e tempo de doença variando de 4 a 17 anos na época do procedimento. Quatro pacientes melhoraram após a primeira avaliação e um manteve-se estável. Todos os pacientes permaneceram sem evidência de doença clínica ou radiológica de 5 a 9 anos após. Com uma seleção cada vez mais criteriosa de pacientes o TACTH pode interromper a disseminação do epítopo e controlar a progressão da doença. Apesar de várias outras opções terapêuticas aprovadas para esclerose múltipla o TACTH continua a ser uma forma de tratamento a ser considerada em casos de doença muito agressiva.

Palavras-chave: Células-tronco; autoenxertos; esclerose múltipla; terapêutica.

Multiple sclerosis (MS) is the most prevalent chronic inflammatory disease that affects the central nervous system (CNS) and is considered to be the prototype of immune-mediated disease caused by autoreactive $\mathrm{T}$ cells $\mathrm{s}^{1}$. Inflammatory reaction targeting the self-CNS myelin and axonal proteinsleads to demyelination and degeneration in multiple areas of white and gray matter, which results in progressive disability in genetically susceptible young people 2 . The most common symptoms are progressive paralysis, sensibility disorder, vision loss, coordination disability, and cognitive impairment ${ }^{3}$.

The currently accepted pathophysiology is that myelinreactive $\mathrm{T}$ cells are activated in the peripheral circulation

'Universidade José do Rosário Vellano, Belo Horizonte, MG, Brasil;

${ }^{2}$ Ecoar Centro de Imagens, Belo Horizonte MG, Brasil.

Elizabeth R. Comini-Frota (iD) https://orcid.org/0000-0002-2702-0402

Correspondence: Elizabeth R. Comini-Frota; Avenida Contorno, 4045 / sala 601;30130-919 Belo Horizonte MG, Brasil. E-mail: elizcomini@gmail.com

Conflict of interest: There is no conflict of interest to declare.

Received 29 September 2018; Received in final form 21 April 2019; Accepted 14 May 2019. 
or peripheral lymph nodes by antigens with which susceptible hosts had been in contact, possibly during childhood, constituting a breach of auto-tolerance to CNS antigens $^{1}$. Later, these $\mathrm{T}$ cells cross the blood-brain barrier and encounter the myelin antigen in the CNS parenchyma, presented by activated microglia, thus initiating an inflammatory response that causes myelin destruction and axon degeneration ${ }^{1}$. As other antigens become exposed through cell destruction, epitope spreading or activation of $\mathrm{T}$ cells and $\mathrm{B}$ cells against multiple other antigens occurs, and the inflammation is thus perpetuated into an inflammatory reaction. Axonal damage and epitope spreading from the outset are two current concepts that support early and effective treatment ${ }^{4}$.

The evidence for inflammation and degeneration in MS has three major parameters: clinical presentation of intermittent neurological deficits (relapses) ${ }^{3}$; appearance and accumulation of lesions seen through magnetic resonance imaging (MRI) as gadolinium-enhanced lesions or new T2-weighted hyperintense lesions ${ }^{5}$; and progression of disability, as measured by the Expanded Disability Status Scale (EDSS) ${ }^{6}$.

There are currently many disease-modifying drugs for MS, and all of them focused on inflammation control ${ }^{7}$. None of the treatments, even the most effective immunosuppression, has been reported to help maintain long-term control of disease progression. Furthermore, the treatments that imposed periods of selective or systemic immunosuppression have high risks of infection and malignant diseases ${ }^{8}$.

Stem cell transplantation enables resetting of the hematopoietic lineage, and the rationale for this treatment in MS is that it renews the immune system and stops disease progression ${ }^{9}$. Since 1996, when autologous hematopoietic stem cell transplantation (AHSCT) started being used for treating MS, more than 1,000 patients with MS have undergone this treatment ${ }^{9}$. In most of these cases, other available treatments had failed, or there was evidence of highly active disease $\mathrm{e}^{10,11,12}$.

Patient selection has improved since the beginning. Today, enough knowledge and experience have been accrued to include mainly patients with high disease activity, with less time since disease onset, and without any response to any other medication ${ }^{12}$. No phase III controlled studies have yet been conducted because of the implicit difficulty of implementing a placebo arm or a blind evaluation within such studies ${ }^{11}$.

We report on five patients who underwent AHSCT between 2009 and 2011, and were followed up by clinical and imaging evaluations since then.

\section{METHODS}

The patients were from a reference MS center in Belo Horizonte, MG, Brazil. They were selected and referred to
Ribeirão Preto, SP, Brazil, to undergo AHSCT at the university hospital (Hospital das Clínicas, Ribeirão Preto Medical School, Universidade de São Paulo), between January 2009 and April 2011. Eleven patients were selected during the same period for the procedure; however, only five had the financial funds to support their access to the hospital, because they had to travel and stay in another town, which is $500 \mathrm{~km}$ from our city.

The methods used here for AHSCT have been described elsewhere by the responsible teams ${ }^{9,13}$ and are not within the scope of this report. In summary, the five patients were treated with cyclophosphamide (12 g) for a conditioning regimen, considered a nonablative therapy, according to the protocol of the transplantation center at that time ${ }^{13}$. After the procedure, the patients returned to the original MS center in Belo Horizonte and were evaluated every six months up to July 2018, with complete EDSS evaluation, MRI imaging, and clinical examination, by the same neurologist. The patients were imaged at baseline and followed up with the same 1.5T MRI scanner (General Electric, HDX). The sagittal and coronal FLAIR T2, and sagittal and coronal T1 sequences, before and after gadolinium, were evaluated by the same radiologist. A total of 67 MRIs and 268 sequences were evaluated and compared. The lesions were counted and measured.

The other six remaining patients, who were selected for the AHSCT during the same period but could not undergo the procedure, were assessed in 2018 to compare the evolution of the disease in this group.

\section{RESULTS}

In the first evaluation, six months after the procedure, four patients had improvement in their EDSS degree of disability, and one of them was stabilized. After five years, there were no relapses, no new T2 lesions, no gadolinium-enhanced lesions, or EDSS progression; this meant that they remained without disease activity. One patient moved to a city far from Belo Horizonte and was being followed at the local center. Despite our report of no more MRI lesions or clinical evidence of disease activity, he started oral medication and was lost to our follow-up. Four patients continued the follow-up without evidence of disease activity for seven to nine years. Table 1 shows the patients' age, age at disease onset, relapses one year before the EDSS evaluation just before the AHSCT, EDSS scores after one and five years of follow-up and at the last visit, and MRI results in the same period. None of the remaining patients were using any medication during the follow-up period. The Figure shows a timeline for each patient who underwent AHSCT, and the clinical relapses before and after the procedure.

At the last evaluation, patients were asked about their experience with the AHSCT, and all five patients answered 
Table 1. Clinical profile of five patients who underwent autologous hematopoietic stem cell transplantation (AHSCT), before and after treatment.

\begin{tabular}{|c|c|c|c|c|c|}
\hline Variable & Patient 1 & Patient 2 & Patient 4 & Patient 4 & Patient 5 \\
\hline Sex & Female & Female & Male & Female & Female \\
\hline Age of onset & 33 & 34 & 23 & 37 & 16 \\
\hline Disease duration & 17 & 14 & 4 & 10 & 9 \\
\hline New T2 lesions one year before treatment & 5 & 5 & 9 & 4 & 11 \\
\hline Relapses one year before treatment & 3 & 5 & 8 & 3 & 6 \\
\hline \multirow{5}{*}{ Treatments before AHSCT } & MP & MP & MP & MP & MP \\
\hline & INFb & INFb & INFb & INFb & INFb \\
\hline & $\mathrm{CY}$ & Gad+ & $\mathrm{CY}$ & & IVIg \\
\hline & MTX & IVlg & & & \\
\hline & & $\mathrm{CY}$ & & & \\
\hline Predominant symptom localization & $\begin{array}{l}\text { cerebellar, } \\
\text { spinal }\end{array}$ & $\begin{array}{l}\text { cervical/ } \\
\text { proprioception }\end{array}$ & cervical/motor & thoracic/motor & brainstem \\
\hline EDSS score before treatment & 5.5 & 6.5 & 6 & 6 & 4.5 \\
\hline EDSS score 5 years after treatment & 4.5 & 6 & 4.5 & 6 & 3 \\
\hline EDSS final evaluation 2018 & 4.5 & 6 & - & 6 & 3 \\
\hline Period of no evidence of disease activity (years) & 9 & 8 & 5 & 7 & 9 \\
\hline
\end{tabular}

05, 15, 1965 First Relapse

(1)

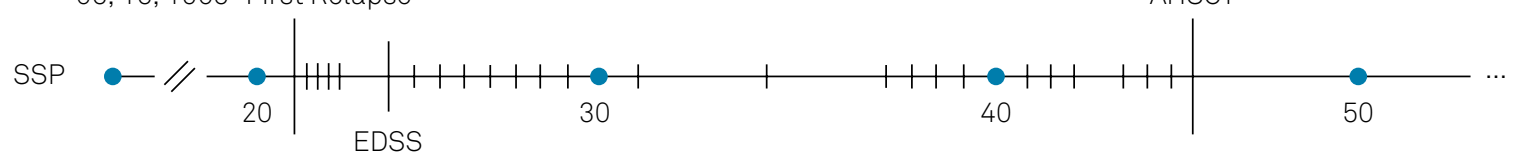

3.0

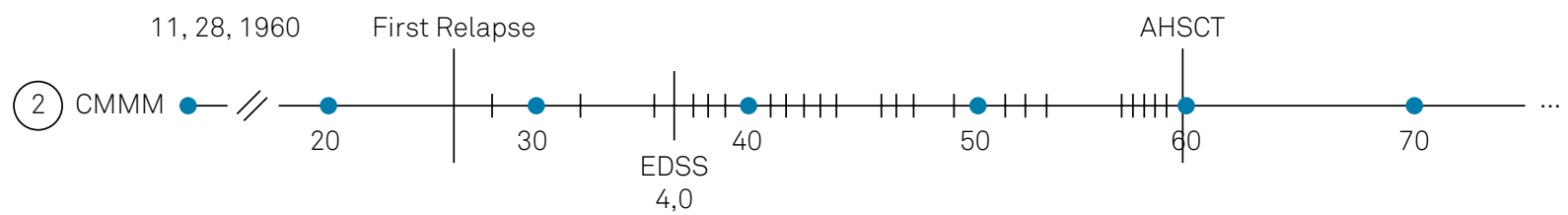

03, 30, 1982
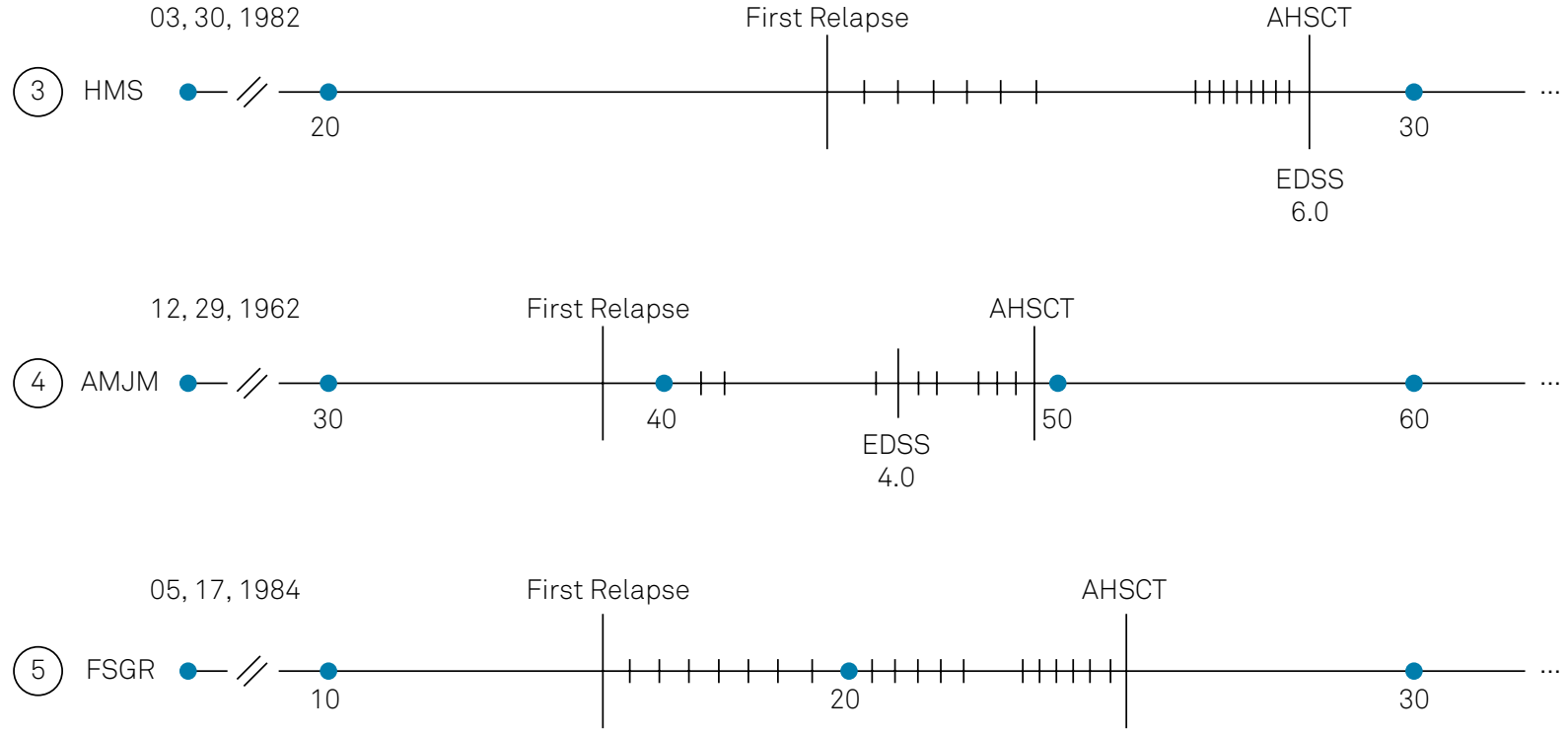

Figure. Clinical relapses of each patient before and after autologous hematopoietic stem cell transplantation (AHSCT). 
Table 2. The results of the 2018 evaluation of six patients who were selected previously but could not undergo the treatment with AHSCT.

\begin{tabular}{|c|c|c|c|c|c|c|}
\hline Variable & Patient 6 & Patient 7 & Patient 8 & Patient 9 & Patient 10 & Patient 11 \\
\hline Sex & Female & Male & Female & Male & Female & Male \\
\hline Age of onset & 16 & 19 & 15 & 28 & 40 & 21 \\
\hline Disease duration 2018 & 18 & 19 & 19 & 27 & 14 & 19 \\
\hline \multirow{3}{*}{ Treatments before 2010} & MP & MP & MP & MP & MPS & MP \\
\hline & INFb & INFb & INFb & INFb & INFb & INFb \\
\hline & & Cy & & Cy & Cy & IVlg \\
\hline \multirow{3}{*}{ Treatments after 2010} & NTZ & & NTZ & CY & NTZ & \\
\hline & FNG & NTZ & FNG & FNG & FNG & none \\
\hline & $A L Z$ & & ALT & & & \\
\hline $\begin{array}{l}\text { Predominant symptom } \\
\text { localization }\end{array}$ & thoracic & cervical & $\begin{array}{l}\text { brainstem } \\
\text { cerebellar }\end{array}$ & thoracic & $\begin{array}{l}\text { thoracic } \\
\text { brainstem }\end{array}$ & cervical \\
\hline EDSS 2010 & 4.0 & 5.5 & 4.5 & 6 & 4.0 & 5.5 \\
\hline EDSS 2018 & 7.0 & 8.0 & 7.0 & $\begin{array}{c}8 \text { (deceased } \\
\text { 2018) }\end{array}$ & 6.0 & $\begin{array}{c}10 \text { (deceased } \\
\text { 2015) }\end{array}$ \\
\hline $\begin{array}{l}\text { Clinical form of disease after } \\
2010\end{array}$ & RRMS & SPMS & RRMS & SPMS & RRMS & SPMS \\
\hline
\end{tabular}

AHSCT: autologous hematopoietic stem cell transplantation; EDSS: Expanded Disability Status Scale; NTZ: natalizumab ; ALT: alemtuzumab; FNG: fingolimod; INFb: interferon beta; MP: methylprednisolone; CY: cyclophosphamide; RRMS: relapsing-remitting MS; SMS: secondary-progressive MS.

that they would undergo the treatment again to be free of disease, if they needed to. All of them had signed an informed consent for this report.

To improve the strength of our results, we show the results of the 2018 evaluation of six patients who were previously selected but could not undergo the treatment with AHSCT (Table 2). Two patients in this group had died. The first one had refused to use any approved medications since 2010 and had a very aggressive disease, and the other had a urinary tract infection while on fingolimod therapy and died as a consequence of septicemia.

\section{DISCUSSION}

Considering that all five patients had high disease activity, these results show a very good outcome for all of them.

Sormani et al. ${ }^{7}$ compared the results of two Swedish studies, with 24 and 41 patients, that reported the proportion of patients with no evidence of disease activity (NEDA) at the five-year follow-up after AHSCT, with the proportion of patients that remained NEDA under other therapies. The proportion of NEDA patients after AHSCT was $83 \%$ at two years and $60 \%$ at five years in a single-arm study, and $78 \%$ at two years and $68 \%$ at five years in an observational study.

Reviewing current treatments, such as monoclonal antibodies, in two alemtuzumab and one ocrelizumab studies, the patients that remained NEDA were under $39 \%$ at the three-year follow-up ${ }^{8,9}$. The body of evidence accumulated about AHSCT suggests that this therapy could be more effective in stopping disease activity than any other therapy, in a longer follow-up.

Muraro et al. ${ }^{14}$, in a recent review, confirmed that AHSCT is a treatment to be used to rescue aggressive disease after an escalating therapy, exactly as occurred in our patients. In that review, the authors postulated that the results of the first publications about AHSCT were not accurate, because most of the patients who underwent this therapy during the initial years had secondary-progressive disease. Through improving patient selection and decreasing the time since disease onset, AHSCT could stop disease progression. According to those authors, the five trials published since 2010 reported $82 \%-93 \%$ of patients with NEDA after two years of follow-up. This is the most important result in controlling disease activity considering all treatments.

According to Muraro et al. ${ }^{14}$, the mortality and adverse events of the treatment depend mostly on the intensity of the conditioning regimen, the clinical condition of the patients, their age, and comorbidities. The mortality rate has decreased dramatically since the first reported patients, calculated to be $7.3 \%$ in the earliest patients reported before the year 2000 , to $0.2 \%$ in the past five years ${ }^{14}$. This decrease has been attributed to many causes, such as nonablative conditioning regimens that have started being used since 2005, the restricted selection of the patients, especially focusing on relapsing-remitting disease instead of progressive, less time of disease duration and lower EDSS scores, better monitoring, and prophylaxis of infections. Our patients were all submitted to a nonablative conditioning regimen, all had relapsing-remitting MS, and none of them had any comorbidity. 
The major predictable adverse events are secondary infections, amenorrhea, alopecia, and permanent infertility. Among our patients, three women who underwent the treatment after 45 years of age had permanent amenorrhea after the treatment, whereas the youngest patient recovered after a year of the treatment and achieved regularity in her menstruation cycles.

The advantage of AHSCT over other currently approved drugs for MS, such as alemtuzumab, ocrelizumab, and natalizumab, is the time of immunosuppression and the speed and the quality of the recovered immune system. After complete depletion of the immune cells, the reinfusion of CD34 stem cells develops a "new" immune system where TCD8, natural killer cells, and B cells repopulate in the first few weeks; meanwhile, the CD4 naive T cells reemerge and are positively selected and matured in the thymus again, producing a new repertoire in two years ${ }^{15}$. The patients remain immunosuppressed for less time than the other treatments and, after a while, they have a completely new immune system. However, there are not any studies comparing standard treatments with AHSCT.

The importance of our report is that it is the first in Brazilian patients after AHSCT and a lengthy follow-up by the same neurologist, even though it included only a few patients. We aimed to bring attention to the necessity of costversus-efficacy and harm-versus-efficacy studies comparing current medications with AHSCT, especially monoclonal antibodies, to possibly stimulate public university hospitals to perform the procedure.

In conclusion, treatment with AHSCT has implicit difficulties, given its need for specific facilities and its very restrictive inclusion criteria, but it should be considered in cases of very active disease that do not respond to other treatments. Considering the high cost of the current therapies and the risk of death through the long-term use of immunosuppressive therapies, AHSCT is still an option for select patients.

\section{References}

1. Martin R, Sospedra M, Rosito M, Engelhardt B. Current multiple sclerosis treatments have improved our understanding of MS autoimmune pathogenesis. Eur J Immunol. 2016 Sep;46(9):2078-90. https://doi.org/10.1002/eji.201646485

2. Nicol B, Salou M, Laplaud DA, Wekerle H. The autoimmune concept of multiple sclerosis. Presse Med. 2015 Apr;44(4 Pt 2):e103-12. https://doi.org/10.1016/j.lpm.2015.02.009

3. Krieger SC, Cook K, De Nino S, Fletcher M. The topographical model of multiple sclerosis: A dynamic visualization of disease course. Neurol Neuroimmunol Neuroinflamm. 2016 Sep;3(5):e279. https://doi.org/10.1212/NXI.0000000000000279

4. Dalla Costa G, Passerini G, Messina MJ, Moiola L, Rodegher M, Colombo B, et al. Clinical significance of the number of oligoclonal bands in patients with clinically isolated syndromes. J Neuroimmunol. 2015 Dec;289:62-7. https://doi.org/10.1016/j.jneuroim.2015.10.009

5. Gumberz J, Mahmoudi M, Young K, Schippling S, Martin R, Heesen $\mathrm{C}$, et al. Short-term MRI measurements as predictors of EDSS progression in relapsing-remitting multiple sclerosis: grey matter atrophy but not lesions are predictive in a real-life setting. PeerJ. 2016 Sep;4:e2442. https://doi.org/10.7717/peerj.2442

6. Kurtzke JF. Historical and clinical perspectives of the expanded disability status scale. Neuroepidemiology. 2008;31(1):1-9. https://doi.org/10.1159/000136645

7. Sormani MP, Muraro PA, Saccardi R, Mancardi G. NEDA status in highly active MS is easily obtained with autologous hematopoietic stem cell transplantation than other drugs. Mult Scler J. 2017 Feb;23(2):201-4.

8. D'Amico E, Ziemssen T, Cottone S. Induction therappy for manegement of early relapsing forms of multiple sclerosis: a clinical opinion. Exp Opin Pharmacth. 2017 Oct;18(15):1553-6. https://doi.org/10.1080/14656566.2017.1367383
9. Michel L, Larochelle C, Prat A. Update on treatment of multiple sclerosis. Presse Med. 2015 Apr;44(4):e137-51. https://doi.org/10.1016/j.lpm.2015.02.008

10. Atkins HL, Bowman M, Allan D, Anstee G, Arnold DL, Bar-Or A, et al. Immunoablation and autologous haemopoietic stem-cell transplantation for aggressive multiple sclerosis: a multicentre single-group phase 2 trial. Lancet. 2016 Aug;388(10044):576-85. https://doi.org/10.1016/S0140-6736(16)30169-6

11. Currò D, Mancardi G. Autologous hematopoietic stem cell transplantation in multiple sclerosis: 20 years of experience. Neurol Sci. 2016 Jun;37(6):857-65. https://doi.org/10.1007/s10072-016-2564-3

12. Saccardi R, Freedman MS, Sormani MP, Atkins H, Farge D, Griffith LM, et al. HSCT in MS international study group. Mult Scler. 2012 Jun;18(6):825-34. https://doi.org/10.1177/1352458512438454

13. Rodrigues MC, Hamerschlak N, de Moraes DA, Simões BP, Rodrigues M, Ribeiro AA, et al. Guidelines of the Brazilian society of bone Marrow transplantation on hematopoietic stem cell transplantation as a treatment for the autoimmune diseases systemic sclerosis and multiple sclerosis. Rev Bras Hematol Hemoter. 2013;35(2):134-43. https://doi.org/10.5581/1516-8484.20130035

14. Muraro PA, Martin R, Mancardi GL, Nicholas R, Sormani MP, Saccardi R. Autologous haematopoietic stem cell transplantation for treatment of multiple sclerosis. Nat Rev Neurol. 2017 Jul;13(7):391-405. https://doi.org/10.1038/nrneurol.2017.81

15. Muraro PA, Douek DC, Packer A, Chung K, Guenaga FJ, Cassiani-Ingoni R, et al. Thymic output generates a new and diverse TCR repertoire after autologous stem cell transplantation in multiple sclerosis patients. J Exp Med. 2005 Mar;201(5):805-16. https://doi.org/10.1084/jem.20041679 